\title{
Study on the characteristics of the Ship's Routing in China coast
}

\author{
Jingqun Huo ${ }^{1, a}$, Chunhui Zhou ${ }^{2, b}$, XuanCheng Zhang ${ }^{3, c}$, Caiyun Xu, Xin Liu \\ and Chaofan Liu
}

\author{
${ }^{1}$ School of Navigation, Wuhan University Of Technology, China \\ ${ }^{2}$ School of Navigation, Wuhan University Of Technology, China \\ ahjq0121512370605@163.com, bchunhui@whut.edu.cn, c359639762@qq.com
}

Keywords: Ship's Routing, China Coast, Comparison, Improvement

Abstract: The Ship's Routing has been widely used in many coastal waters of China. It plays an important role in regulating the traffic flow of ships, guaranteeing the safety of ships and improving the traffic efficiency. According to the standard of international Ship's Routing, combined with the examples of Ship's Routing in coastal areas of China, this paper analyzes and compares some of the Ship's Routing systems implemented in China's coastal areas. It has found out the characteristics and rules. At the same time, it points out some problems. It is of guiding significance for the improvement of the existing Ship's Routing management and the implementation of more new Ship's Routing.

\section{Introduction}

Ship's Routing is recommended by the International Maritime Organization (IMO) to optimize the route of ships ${ }^{[1]}$. It plays a very important role in regulating the traffic flow of ships, guaranteeing the safety of ships and improving the traffic efficiency ${ }^{[2]}$.There are many kinds and types of Ship's Routing. In the current system of Ship's Routing, the traffic separation system is the most common and the most important form of the Ship's Routing ${ }^{[3]}$. Compared with foreign countries, the implementation of Ship's Routing in our country starts late, but it develops very fast. Now the Ship's Routing has been established in the waters of Chengshan Jiao, Pearl River Estuary, LaoTieShan, Qiongzhou Strait and so on.

Our country is planning and making projects of Ship's Routing for more waters, such as the Ship's Routing of the eastern waters in Guangdong, the Ship's Routing of Minjiang port. There are still some key technical problems in the establishment of Ship's Routing. For example, what form of Ship's Routing should be adopted. Some scholars put forward solutions from different aspects. In the design of the dividing strip, Lewison ${ }^{[4]}$ suggested that the width should not be less than 1 nmile if the water conditions permit. If the water conditions are limited, a narrow dividing strip or a buoy on the boundary can be used to remind passing vessels. This paper attempts to analyze and compare for some examples of Ship's Routing in coastal China. Then it finds out the characteristics and rules among them. This paper analyzes the common problems in the management of Ship's Routing. And it provides a useful reference for the improvement and implementation of Ship's Routing.

\section{The implementation (development) of Ship's Routing along the coast in China}

The Ship's Routing that China has implemented includes LaoTieShan waterway, Chengshantou water area, Ningbo Zhoushan waters, the Yangtze River Estuary, waters of the Pearl River Estuary, 
the Qiongzhou Strait and so on. It is shown in figure 1.

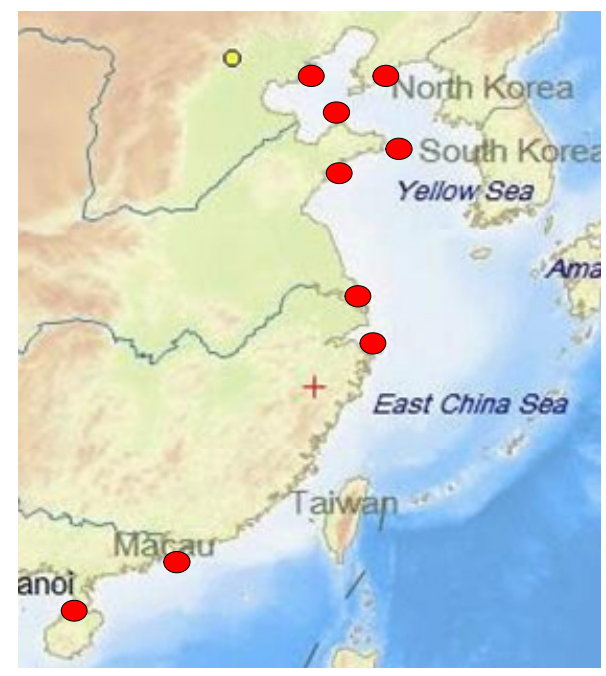

Fig. 1 the distribution map of the main Ship's Routing in coastal waters of China

\section{LaoTieShan waterway}

LaoTieShan waterway is vital to ships sailing in and out of Bohai Sea. There are a large amount of fishing boats and the traffic density is very high. The encounter rate of ships is high as well. The traffic flow of ships is complex. In addition, there are strong wind, high waves, intense currents and thick fog. There are also military restricted zones on both sides of the waterway. The waters is a high frequency accident area. The Ship Routing System for the Waters of LaoTieShan enters into force on April 2007. It works very well currently. There is a dividing strip in the middle of the LaoTieShan waterway, which is nine nautical miles in length and one nautical mile in width. Ships from the Yellow Sea into the Bohai Bay take the westbound traffic lane. Ships from the Bohai Bay into the Yellow Sea take eastbound traffic lane. Crossing traffic lanes will be strictly prohibited. Due to the complexity of the ship's course in the west of LaoTieShan waterway, a precautionary area of 5 nautical miles in radius is set up to remind the ship operators to navigate with caution.

\section{Qiongzhou Strait}

The Ship Routing System for the Waters of Qiongzhou Strait began to implement in January 2007. It consists of many types of Ship's Routing system, such as central dividing strip, border dividing strip, east-west traffic lanes and north-south traffic lanes, precautionary area and avoiding area, the boundary line and the inshore traffic zone. It is running well currently. With the development of economy in Hainan province and the construction of Hainan international tourism island, the density of ships in Qiongzhou Strait will increase greatly. The middle waterway in the eastern part of the Qiongzhou strait is the only channel for ships passing through the Qiongzhou strait. It has always been a frequent collision accident area, because of the complex traffic flow, large traffic volume and the frequent activities of fishing boats. There are many shallow beaches. The water flow here is urgent. And the navigable waters is narrow. To strengthen the traffic safety management of the waters and ensure the safety of navigation effectively, China has put The Qiongzhou Strait waterway into the range of Ship's Routing. It expands the area of Ship's Routing in Qiongzhou Strait as well as protecting the environment here. In addition, it improves the efficiency of transport and reduces the incidence of accidents greatly. 


\section{Xiamen waters}

Xiamen port is located at the Jiulongjiang estuary of Fujian Province. It is an important port on the southeast coast of China and an important traffic port of the Taiwan Strait as well. The waters of Xiamen port is wide, deep, non-freezing and less silt. It is a rare natural harbor on the coast of China ${ }^{[5]}$. With the increasing of the number of ships arriving in Xiamen port, the trend of ship diversification, large scale, specialization and fast speed is more and more obvious. The risk of maritime transport is increasing. The waters of Xiamen began to implement Ship's Routing in July 2015, including a deep water route and three precautionary areas. It reduces the frequency of the ship intersection greatly. It also reduces the risk of pollution or other damage to the marine environment due to the collision, stranding of the vessels in this sensitive area. Therefore, the water traffic safety management level of Xiamen port can be greatly improved.

\section{Changshan channel}

Changshan channel is located in the waters of Yantai, Shandong province. It is between the Houji Island, the North Changshan Island and Daeheuksando Island. The channel is east-west, with a total length of about 23 nautical miles. The average width of the waterway is 3 nautical miles. The narrowest part is 2.2 nautical miles and the water depth is 20-31 meters. It is one of the important Waterborne Transportation Corridors to and from Tianjin, Qinhuangdao, Huanghua, Weifang, Dongying, Longkou, Laizhou, Penglai and other ports ${ }^{[6]}$. The waters of Changshan channel are very foggy. The climate is changeable and the sea conditions are complicated here. It has a great influence on the navigation safety of ships. This area is an important fishing ground along the northern coast of China. And a large fishing area is located on the two sides of the Changshan channel and nearby waters. During the fishing season, a large number of fishing boats are active in the waters of the Changshan channel. And in recent years, with the rapid development of economy and society in Bohai ring area, the traffic flow of Changshan channel has been increasing rapidly. And the density of vessel traffic is increasing. Since the implementation of Ship Routing System for the Changshan channel in January 2009, there's another convenient channel that ships passing in and out of the Strait of Bohai. The Ship's Routing of Changshan waterway is composed of traffic separation area and precautionary area. The center line of dividing strip shall set up the virtual navigation mark. All ships must sail on the right side of the dividing strip. A precautionary area with a radius of 5 nautical miles is set up at both ends of the waters. The maritime sector will strengthen the supervision of ships entering the precautionary area.

\section{A comparison of the characteristics of Ship's Routing in coastal area}

By comparing and analyzing the characteristics of Ship's Routing in several coastal waters, the results are shown in table 1 . 
Table1 comparison of characteristics of Ship's Routing in several coastal waters

\begin{tabular}{|c|c|c|c|c|c|c|c|c|}
\hline $\begin{array}{r}\text { Coastal } \\
\text { Waters } \\
\text { comparison of } \\
\text { characteristic }\end{array}$ & $\begin{array}{c}\text { Lao } \\
\text { TieShan } \\
\text { waterway }\end{array}$ & $\begin{array}{c}\text { Cheng } \\
\text { ShanJiao } \\
\text { waters }\end{array}$ & $\begin{array}{l}\text { Yangtze } \\
\text { estuary } \\
\text { waters }\end{array}$ & $\begin{array}{c}\text { Qiongzhou } \\
\text { Strait }\end{array}$ & $\begin{array}{l}\text { Changshan } \\
\text { waterway }\end{array}$ & $\begin{array}{c}\text { Cao } \\
\text { FeiDian } \\
\text { waters }\end{array}$ & $\begin{array}{c}\text { Grand } \\
\text { three } \\
\text { waterway }\end{array}$ & $\begin{array}{l}\text { Qing Dao } \\
\text { waters }\end{array}$ \\
\hline $\begin{array}{c}\text { The constitution } \\
\text { of Ship's } \\
\text { Routing }\end{array}$ & $\begin{array}{l}\text { Dividing } \\
\text { strip、traffic } \\
\text { seperation } \\
\text { schemes、 } \\
\text { precautionar } \\
\text { y area }\end{array}$ & $\begin{array}{l}\text { Traffic } \\
\text { separation } \\
\text { schemes } \\
\text { dividing } \\
\text { strip、coastal } \\
\text { navigation } \\
\text { zone } \\
\text { precautionary } \\
\text {, area }\end{array}$ & $\begin{array}{l}\text { Traffic } \\
\text { separation } \\
\text { schemes 、 } \\
\text { dividing } \\
\text { strip } \\
\text { Precautiona } \\
\text { ry area }\end{array}$ & $\begin{array}{l}\text { Dividing } \\
\text { strip 、 traffic } \\
\text { lane } \\
\text { precautionary } \\
\text { area } \\
\text { restricted } \\
\text { area } \\
\text { boundary } \\
\text { line , coastal } \\
\text { navigation } \\
\text { zone }\end{array}$ & $\begin{array}{l}\text { Traffic } \\
\text { separation } \\
\text { schemes } \\
\text { dividing } \\
\text { Strip } \\
\text { precautiona } \\
\text { ry area }\end{array}$ & $\begin{array}{l}\text { Traffic } \\
\text { Separation } \\
\text { schemes } \\
\text { dividing } \\
\text { Strip } \\
\text { precautiona } \\
\text { ry area }\end{array}$ & $\begin{array}{l}\text { Traffic } \\
\text { Separation } \\
\text { Schemes } \\
\text { dividing } \\
\text { strip } \\
\text { coastal } \\
\text { navigation } \\
\text { zone }\end{array}$ & $\begin{array}{l}\text { Traffic } \\
\text { Separation } \\
\text { schemes } \\
\text { precautionary } \\
\text { area coastal } \\
\text { navigation } \\
\text { zone }\end{array}$ \\
\hline $\begin{array}{c}\text { Number of } \\
\text { Dividing strip }\end{array}$ & 1 & 4 & 8 & 8 & 4 & 2 & 3 & 2 \\
\hline $\begin{array}{c}\text { Number of } \\
\text { Traffic } \\
\text { lane }\end{array}$ & 1 & 2 & 8 & 4 & 4 & 3 & 1 & 2 \\
\hline $\begin{array}{l}\text { Length of } \\
\text { Dividing } \\
\text { Strip } \\
{[\mathrm{NM}]}\end{array}$ & 9 & I & $1.94-4.61$ & I & $0.8-12.7$ & $5-10$ & $1.2-1.4$ & $3.2-3.5$ \\
\hline $\begin{array}{l}\text { Width of } \\
\text { Dividing } \\
\text { Strip } \\
{[\mathrm{NM}]} \\
\end{array}$ & 1 & 2 & 0.5 & $0.2-0.4$ & 0.2 & 0.5 & 0.3 & $0.3-0.5$ \\
\hline $\begin{array}{c}\text { Number of } \\
\text { Precautionary } \\
\text { area }\end{array}$ & 1 & 2 & 8 & 3 & 3 & 1 & 0 & 3 \\
\hline $\begin{array}{c}\text { Shape of } \\
\text { Precautionary } \\
\text { area } \\
\end{array}$ & circular & circular & $\begin{array}{l}\text { Irregular } \\
\text { shape }\end{array}$ & $\begin{array}{c}\text { Circular } \\
\text { irregular } \\
\text { shape } \\
\end{array}$ & circular & rectangle & I & $\begin{array}{c}\text { Irregular } \\
\text { shape }\end{array}$ \\
\hline $\begin{array}{c}\text { Scale of } \\
\text { Precautionary } \\
\text { area }\end{array}$ & $\begin{array}{c}\text { Diameter } \\
10 \mathrm{NM}\end{array}$ & $\begin{array}{c}\text { Diameter } \\
10 \mathrm{NM}\end{array}$ & I & $\begin{array}{c}\text { Diameter } \\
4 \mathrm{NM}\end{array}$ & $\begin{array}{c}\text { Diameter } \\
5 \mathrm{NM}\end{array}$ & $\begin{array}{c}\text { Length } \\
4 \mathrm{NM} \\
\text { width } \\
2.5 \mathrm{NM} \\
\end{array}$ & I & I \\
\hline $\begin{array}{c}\text { Scale of } \\
\text { Traffic lane } \\
\text { [NM] }\end{array}$ & $\begin{array}{l}\text { Width } \\
2.25 \text { 、 } \\
\text { Length } 9\end{array}$ & Width 2 & $\begin{array}{l}\text { Width } \\
1.0-1.6\end{array}$ & Width $1.3-2.2$ & $\begin{array}{l}\text { Width } \\
1.0-3.7 \\
\text { Length } \\
9.8-14.7 \\
\end{array}$ & $\begin{array}{l}\text { Width } \\
0.6-1 \\
\text { length } \\
3.2-10\end{array}$ & $\begin{array}{l}\text { Width } \\
1.42 \\
\text { length } 1.21\end{array}$ & $\begin{array}{l}\text { Width } \\
0.30-0.72 \\
\text { length } \\
1.77-3.49 \\
\end{array}$ \\
\hline $\begin{array}{c}\text { Trend of } \\
\text { Traffic } \\
\text { lane }\end{array}$ & East-west & south-north & $\begin{array}{l}\text { East-west } \\
\text { south-north }\end{array}$ & $\begin{array}{l}\text { East-west } \\
\text { south-north }\end{array}$ & East-west & East-west & $\begin{array}{c}\text { South-nort } \\
\mathrm{h}\end{array}$ & East-west \\
\hline $\begin{array}{l}\text { Main direction } \\
\text { of } \\
\text { vessel traffic } \\
\text { flow } \\
\end{array}$ & $300^{\circ} / 120^{\circ}$ & $\begin{array}{c}000^{\circ} 、 330^{\circ} \\
150^{\circ}, 180^{\circ}\end{array}$ & I & $\begin{array}{c}261^{\circ} / 081^{\circ} / 35 \\
0^{\circ} / 170^{\circ}\end{array}$ & $\begin{array}{l}282^{\circ} \% \\
102^{\circ}\end{array}$ & $\begin{array}{l}278^{\circ} \% \\
098^{\circ}\end{array}$ & $000^{\circ} / 178^{\circ}$ & $283^{\circ} / 103^{\circ}$ \\
\hline
\end{tabular}

In recent years, China's coastal areas have become one of the busiest maritime waters in the world, with the increasing of traffic flow and traffic density. With the purpose of improving the traffic safety of ships along the coast and reducing ship traffic accidents, the Maritime Safety 
Administration of China came up with the <Overall planning of the national coastal Ship's Routing system > in December 2011.

As can be seen from the table 1, the traffic separation system is a common means of water traffic management. It is also an important one in the system of Ship's Routing in coastal waters of our country. Furthermore, precautionary area and inshore traffic zone are also common measures of Ship's Routing system. The number of dividing strip varies with the complexity of the environment in the waters of the Ship's Routing system. Generally speaking, the more complicated the water environment is, the more dividing strips and precautionary areas are. The dividing strip can divide the traffic flow in opposite directions and separate the coastal navigation belt from the adjacent traffic lanes. Simultaneously its width shall be no less than 3 times the standard error lateral component of the optimum positioning method. The shape of the precautionary area can be not only circular, but also a closed graph connected by several points. Its scale is determined by the competent authorities in full consideration of the navigation environment and order, the dangerous situation of the waters in history and the comprehensive analysis of the accident conditions. In the region, special care must be taken in sailing. Generally speaking, the direction of the traffic lane is east-west or north-south. And the ships sailing in the waters should strictly abide by it. The traffic density, traffic flow, the positioning accuracy of the traffic lane, the minimum safe distance of ship overtaking, as well as the available width and depth of water should be considered together when determining the scale of the traffic lane. For the designated direction of the ship traffic flow, the vessels are supposed to sail along with it.

\section{Problems existing in the management of coastal ship's routing}

\section{The problem of crowded traffic flow meeting in the precautionary area}

For quite some time, there has been a common problem that the crowded traffic flow encounters in the precautionary area. And it has been widespread in the coastal waters of Ship's Routing in our country all the time. Taking The Lao Tieshan waterway for instance, the VTS project team of Dalian Mariner Transport School, Yicheng Jin ${ }^{[7]}$ et al studied the traffic management scheme of the ships in 1992. And they give the qualitative analysis as well. After analysis, we have got a conclusion that the implementation of traffic separation scheme can reduce the encounter rate to zero. But the meeting rate and delay time are almost unchanged near the crossing. It shows that the traffic separation scheme does not solve the problem that the ships encounter in this area ${ }^{[8]}$. We can see from Figure 2 that the channel 1 is Lao Tieshan waterway. The channel 2 is the passage from Lao Tieshan waterway to Qin Huangdao. The channel 3 is the passage from the Lao Tieshan waterway to Tianjin. The nodes A, B and D are the entrances and exits of the above channels. And the node $\mathrm{C}$ is the crossing point of the above channels.

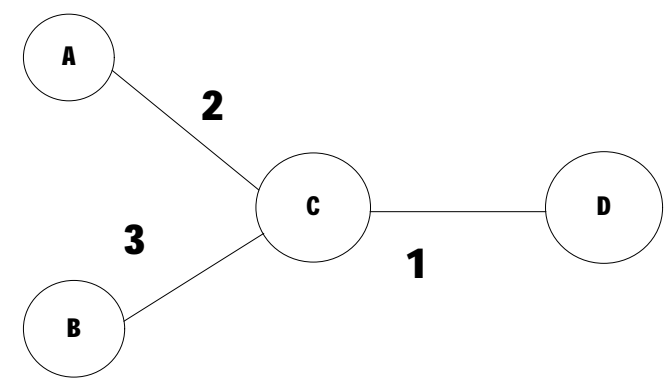

Figure 2 the traffic flow analysis diagram of Lao Tieshan waterway 


\section{Problem of fishing vessel}

There are some problems in the coastal waters of our country widespreadly, such as the intensive operation of fishing vessels and the disorderly navigation of fishing boats. The implementation of Ship's Routing system has no substantial influence on fishing vessels. Fishing vessels have small body and good flexibility. And they are unstable in course and speed. In addition, they do not report or listen to the traffic control channel when they work. During closed fishing season, there are still a great deal fishing boats in operation. What's more, the waterway is more crowded by fishing boats during fishing time. It makes the merchant vessel navigate off an intended course for avoidance, which may give rise to misunderstanding and unnecessary trouble.

\section{Problem of not obeying Ship's Routing}

The situation of foreign ships sailing in and out the coastal waters of China is not good. Because they don't obey the Ship Reporting System. Generally speaking, the most foreign ships can follow the traffic separation schemes in their voyage. But the situation of obeying Ship Reporting System is not ideal. If the foreign ships do not contact with transport supervisors actively or listen to the working channel when sailing across report line, it will make it difficult to get in touch. If there is a situation of ships meeting or ships avoiding, transport supervisors will get into more troubles.

In addition, a very few ships neither follow the traffic separation schemes nor keep watch on VHF. These are mainly small vessels running on the coast of China and a few foreign vessels. These ships sail across the dividing strips and take the back course, which seriously violates the regulations of traffic separation schemes. The ships of our country running along the coastal waters aim at saving distance. While the foreign ships do it due to the barriers on language that makes them sail illegally. It can be said that these vessels are one of the biggest security threats in the Ship's Routing System for the waters of China. It's difficult for the transport supervisors to get in touch with these ships. If those vessels go into the back course again, it will bring great danger to ships sailing in accordance with the system of traffic separation schemes. Traffic controllers can only organize other boats to make way for them.

\section{Conclusion}

This paper summarizes the current situation of Ship's Routing implemented in coastal waters of our country. And then it analyses and compares their characteristics in detail. In addition, it finds out some characteristics and rules of them. Meanwhile, it points out some problems existing in China's coastal waters. Furthermore, it provides a lot of useful references for our country to make the plan of Ship's Routing system.

\section{References}

[1] International Maritime Organization. General Provisions On Ships’Routeing, 1977.

[2] Christiansen M, Fagerholt K, Ronen D. Ship Routing and Scheduling: Status and Perspectives[J]. Transportation Science, 2004, 38(1):1-18.

[3] Wenhua Xu. Study on the design of traffic separation scheme [D].Dalian Maritime University, 2012.In Chinese

[4] Lewison G R G. The Estimation of Collision Risk for Marine Traffic in UK Waters[J]. Journal of Navigation, 1980, 33(3):317-328. 
[5] Zhenping Shao, Ailin Li, Zhennan Xiong, Lufeng Chen. Study on Ship's Routing system of waters near Xiamen Bay [J]. Navigation of China, 2005, (04):53-55+60. [2017-09-07].In Chinese

[6] Weijie Gao. Study on Optimization of Ship's Routing system in the eastern sea area of Bohai Strait [D].Wuhan University of Technology ,2009.In Chinese

[7] Yichen Jing, Yisheng Zhao. Application of marine traffic simulation to feasibility demonstration of VTS scheme in Dalian Port waters [J]. Journal of Dalian Maritime College ,1992,(01):61-68. In Chinese

[8] Zhaolin Wu. 《Marine traffic engineering》.Dalian Mariner Transport School,1993.In Chinese 